\title{
Effect of Nicotiana tabacum Extract Concentration as Biopesticide on protein content of Robusta coffee beans and skin
}

\author{
Tyas Soemarah Kurnia Dewi ${ }^{1}$, Supartini ${ }^{2}$, Haryuni ${ }^{3}$, Endang Suprapti ${ }^{4}$, Sapto \\ Priyadi $^{5}$, Didik Dwi Ardiyanto ${ }^{6}$, Achmadi Priyatmojo ${ }^{7}$, Misri Gozan ${ }^{8}$ \\ 1,2,3,4,5,6 Faculty of Agriculture, Tunas Pembangunan University. Surakarta, Central Java, Indonesia; \\ ${ }^{7}$ Faculty of Agriculture, Gadjah Mada University. Yogyakarta, Indonesia \\ ${ }^{7}$ Industrial Bioprocess Enginering Resarch Group, Chemical Engineering Department, Faculty of \\ Engineering, Universitas Indonesia. Depok. Indonesia \\ Coresponding Email: tskdmp@gmail.com
}

\begin{abstract}
Tobacco is a plantation commodity used as the main ingredient of cigarettes. Nicotiana tabacum extract as biopesticides are nicotine content, d-limonene, pyridine, and indole on tobacco used as pest control of plants. This study examined the Effect of Nicotiana tabacum Extract Concentration as Biopesticide on protein content of Robusta coffee beans and skin. The research was conducted in March until August 2017 at Kebondalem, Jambu, Semarang with altitude of 711 meters above sea level. The study was designed a singlefactor of complete randomized block design. The concentration consisted of $0 \%, 0.1 \%, 0.2 \%, 0.3 \%, 0.4 \%$ named as $\left(T_{0}, T_{1}, T_{2}, T_{3}\right.$ and $\left.T_{4}\right)$ each treatment repeated 3 times. The results showed that the treatment without Nicotiana tabacum extract was very significant rather than with Nicotiana tabacum extract. The results of this research shows that the highest content of coffee beans protein was $0,75 \%\left(\mathrm{~T}_{0}\right)$, and the lowest was $\left.0.47 \% \mathrm{~T}_{4}\right)$ While the highest content of coffee skin protein content was $1,46 \%\left(\mathrm{~T}_{0}\right)$, and the lowest was $0.38 \%\left(\mathrm{~T}_{4}\right)$.
\end{abstract}

Keywords: Nicotiana tabacum extract, biopesticides, protein

\section{Introduction}

Tobacco is a plantation commodity that used as the main ingredient of cigarettes. Tobacco commodities and cigarette products have high economic value and a source of farmers' income, domestic government revenues and employment opportunities. This makes the cigarette industry as one of the irreplaceable industries in the country, while the fact that many people want to stop the industry because of the negative effects which caused by cigarettes. But if the tobacco industry is stopped, this has a negative impact on the lives of tobacco farmers, government's income and eliminating one of employment opportunities chance in Indonesia. In another side of the dangers effect of the raws cigarettes material, tobacco has other functions that are not widely known, namely as a biopesticide (Dawitri, 2013).

Biopesticides are pesticides which come from plants as basic ingredients, living materials or organic matter. The content of chemicals in plants shows bioactivity in insects, such as repellent, antifeedant, insect growth regulators, and oviposition deterrent (Listiyani, 2012). Chemical pesticides which produced from organic materials are known to be safe for the nutritional content of food crops because of their easily degraded nature, so as not to leave residues in the plants. Tobacco plants can be used as biopesticides because they have compounds that have a function as pesticides that are used as control of plant pests, among others are nicotine, d-limonene, pyridine, and indole (Dawitri, 2013).

Coffee plants contain nutrients such as carbohydrates $(60 \%)$, protein $(13 \%)$, fatty acids such as linoleic acid (39\%), stearic acid $(13.1 \%)$, oleic acid $(17.2 \%)$, arachidat acid (4.2\%), palmitate acid (25.3\%), behenic acid $(1 \%)$, and caffeine $(2.0 \%)$ (Rita, 2012) One of the nutrients found in coffee plants is protein. Proteins are organic substances that contain carbon, hydrogen, nitrogen, oxygen, sulfur, and phosphorus. Protein is needed by every organism and microorganism in its survival. Protein is useful for cell metabolism, tissue formation (Muhsafat, 2015). Protein is very useful for the growth and development of insects, so the protein content found in coffee beans can increase the risk of insect pests such as coffee fruit borer (PBKo) (Hypothenemus hampei) which is the main pest of coffee berries, where PBKo pests will utilize protein in the continuity of its life cycle.

This study aims to examine the effect of the concentration of Nicotiana tabacum extract 
as a biopesticide on the protein content of robusta coffee beans and skin. In addition, this study is useful for students of biology education programs in studying animal biology, especially insects, namely coffee fruit borer. in coffee fruit borer can be learned about the life cycle, the active phase of life that attacks objects, the type of mouth tool and how to attack objects.

\section{Methods}

The study was conducted from February to 15 July 2018 at Rejosari, Jambu Semarang, Central Java. This study uses a Complete Randomized Block Design (RAKL) consisting of a single factor. This factor is the concentration of tobacco biopesticides as follows: T0; T1; T2; T3: T4 (0\%, 0.1\%; 0.2\%; $0.3 \% ; 0.4 \%$ ).

Observations in this study include protein content of seeds and coffee bean bark using the Kjeldahl method (Henni, 2015). The data obtained were analyzed using analysis of variance and what if significantly different then continued using the Duncan Multiple Range Test (DMRT) with a level of 5\%.

\section{Results and Discussion}

\subsection{Protein Levels in Coffee Beans (Coffea} sp.)

To find out the results of the analysis of protein levels in coffee beans (Coffea sp.) Can be seen in Figure 1.

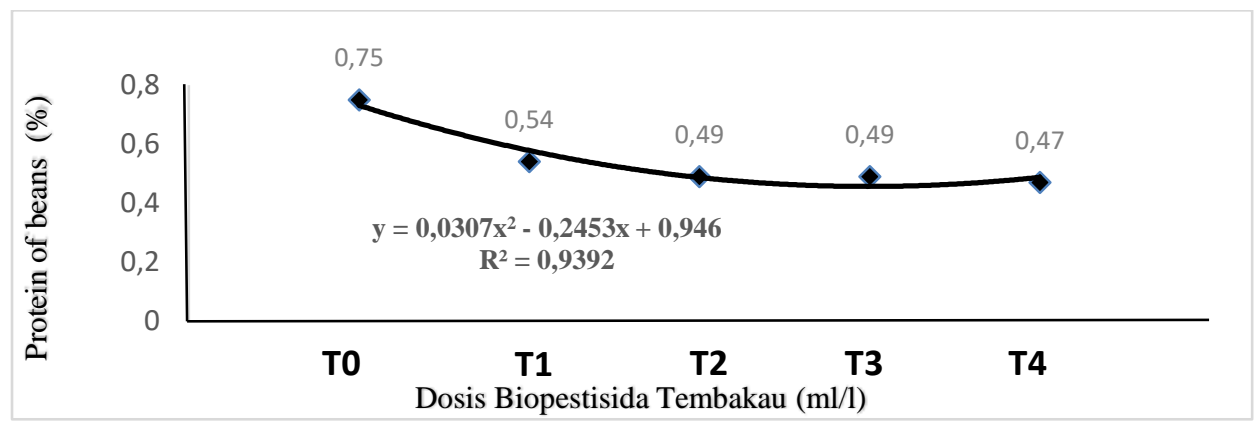

Figure 1. Protein Levels in Coffee Beans

From figure 1. It can be seen that the highest protein content in coffee beans is obtained from T0 treatment and the lowest protein content in T4 treatment. From Figure 1 shows that the higher the concentration of tobacco biopesticides decreases protein levels in coffee beans. Decrease in protein levels because protein is used to reduce toxins stored in plants. Reduction of toxins can be done with protein, thereby reducing the accumulation of residues / deposits of harmful pesticides to agricultural products (Nina, 2007).

Tobacco which acts as a biopesticide is nicotine which is the main alkaloid of tobacco, nicotine acts as an insecticide is nicotine content of $2-8 \%$ depending on tobacco species. Nicotine is the main alkaloid compound in tobacco leaves that is active as an insecticide. Nicotine is believed to be a potential nerve poison and is used as a raw material for various types of insecticides or is a very strong addictive substance (Amri, 2015).

\subsection{Protein Levels in Coffee Beans (Coffea sp.)}

To find out the results of the analysis of protein content in coffee beans (Coffea sp.) Can be seen in Figure 2. The protein content in coffee bean skin was analyzed using the Kjedahl method. 


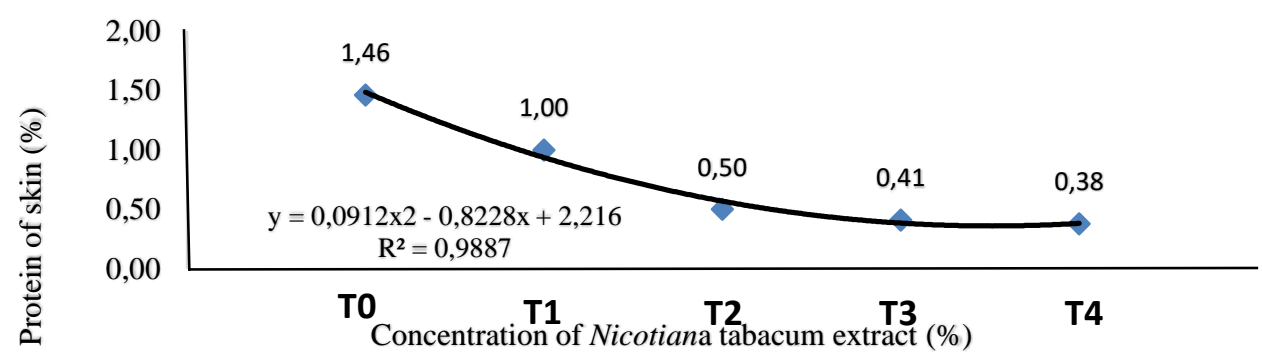

Figure 2. Kadar Protein pada Kulit Biji Kopi (Coffea sp.)

The parameters of the protein content of coffee bean skin showed that the highest seed skin protein content was obtained from T0 treatment and the lowest protein content in $\mathrm{T} 4$ treatment (figure 2). The increase in the concentration of tobacco biopesticides is directly proportional to the decrease in protein levels in coffee bean skin, meaning that the higher the concentration given, the lower the protein content. Not all pesticides can be reduced by protein, tobacco biopesticides can be reduced by coffee bean protein (figure 2). The ability to reduce pesticide content in coffee bean shells is influenced by enzymes produced by plants (Nina, 2007).

\section{Conclusion}

From the results of the study it can be concluded that by increasing the concentration of biopesticides it will reduce the protein content in the beans and coffee bean shells.

\section{References}

Amri Aji, Leni Maulinda, Sayed Amin. 2015. Isolasi Nikotin Dari Puntung Rokok Sebagai Insektis. Jurnal Teknologi Kimia Unimal 4 (1): 100-120. http://ojs.unimal.ac.id

Dawitri, E. 2013. "Biopesticide Production fro Tobacco Leaves by Pyrolysis". Undergraduate Thesis. Universitas Indonesia..

Henni Rosaini, Roslinda Rasyid,Vinda Hagramida. 2015. Penetapan Kadar Protein Secara Kjeldahl Beberapa Makanan Olahan Kerang Remis (Corbiculla moltkiana prime.) Dari
Danau Singkarak Jurnal Farmasi Higea $7 \quad$ (2) : 120-127. https://www.jurnalfarmasihigea.or

Listiyani, A.K., U. Nurkalis., Sudiyanti., R. Hestiningsih. 2012. Ekstraksi Nikotin dari Daun Tembakau (Nicotina tabacum) dan Pemanfaatannya Sebagai Insektisida Nabati Pembunuh Aedes Sp. Jurnal Ilmiah Mahasiswa, 2 (2): 67-70. https://ejournal.undip.ac.id/

Misri Gozan, Yasman, Praswasti P.D.K. Wulan, Ellen Dawitri. 2014. Tobacco Leaves Pyrolysis for Repellent Active Compound Production. International Journal of Applied Engineering Research 9 (21): 9739-9749.

Muhsafaat, La Ode. Heri Ahmad Sukria, Suryahad. 2015. Kualitas Protein dan Komposisi Asam Amino Ampas Sagu Hasil Fermentasi (Aspergillus niger) Dengan Penambahan Urea Dan Zeolit. Jurnal Ilmu Pertanian Indonesia (JIPI). 20 (2): 124-130. http://journal.ipb.ac.id

Nina Hermayani Sadi, T Widiyanto, A Taufik . 2007. Cadmium Bioremoval Of Anoxygenic Photynthethics Bacteria(APB): Absorption Characteristic Within Cell.. Limnotek: perairan darat tropis di Indonesia 14 (1), 1-9.

Rita Hayati, Ainun Marliah, dan Farnia Rosita. 2012. Sifat Kimia Dan Evaluasi Sensori Bubuk Kopi Arabika. J. Floratek 7: $66 \quad-75$. www.jurnal.unsyiah.ac.id 